\title{
PENGARUH PERSEPSI, MOTIVASI DAN HAMBATAN TERHADAP KEIKUTSERTAAN PROGRAM KEMITRAAN DAN KESEJAHTERAAN UKM DI PROVINSI JAMBI (PT. AP II BANDARA SULTAN THAHA JAMBI)
}

\author{
THE INFLUENCE OF PERCEPTION, MOTIVATION AND OBSTACLES ON PARTNERSHIP AND WELFARE
} PARTNERSHIP PROGRAM TO THE SME IN JAMBI PROVINCE (PT. AP II SULTAN THAHA JAMBI AIRPORT)

\author{
Bobit Kowanus Utomo ${ }^{*}$, Arief Daryanto**), dan Lilik Noor Yuliati***) \\ *) PT. Bank Negara Indonesia (Persero) Tbk \\ Jl. Lada no. 1 Jakarta Kota 11110 \\ ${ }^{* *}$ Sekolah Bisnis, Institut Pertanian Bogor \\ Jl. Raya Pajajaran, Bogor 16151 \\ ${ }^{* * *}$ Departemen Ilmu Keluarga dan Konsumen Fakultas Ekologi Manusia Institut Pertanian Bogor \\ Jl. Lingkar Akademik, Kampus IPB Dramaga, Bogor 16680
}

\begin{abstract}
This study aims to identify Partnership Program to provide assistance to the SME community in Jambi province; analyze the perceptions, motivations and barriers in participating in the partnership program; analyze the influence of partnership on the welfare program participation of SMEs in Jambi province; and to analyze the level of well-being before and after the Partnership Program. This research uses descriptive and quantitative approach using primary data collected through surveys. The research subject is determined by random sampling technique, namely to SMEs assisted partner PT. AP II Airport St. Taha Jambi. The sampling technique classified probability sampling using the formula Slovin $(e=5 \%)$ obtained 156 respondents. The data collection was done by interview through a questionnaire. Data analysis was performed using analysis across. The results of this study indicate that the partnership program to provide assistance to the SME community in the province of Jambi were successfully conducted in accordance with the mandate of the regulation of the Minister of State Enterprises, perceptions and motivations significant effect on the partnership program, while barriers no significant effect on the partnership program, participation program partnership a significant effect on the welfare of SMEs in the province of Jambi and changes in the level of welfare significant effect on the SME Partnership Programme.
\end{abstract}

Keywords: perception, motivation, barriers, and prosperity partnership program SMEs

\begin{abstract}
Abstrak: Penelitian ini bertujuan mengidentifikasi Program Kemitraan dalam memberikan bantuan bagi UKM masyarakat di Provinsi Jambi; menganalisis persepsi, motivasi dan hambatan dalam mengikuti program kemitraan; menganalisis pengaruh keikutsertaan program kemitraan terhadap kesejahteraan UKM di Provinsi Jambi; serta menganalisis tingkat kesejahteraan sebelum dan sesudah Program Kemitraan. Penelitian ini menggunakan pendekatan deskriptif dan kuantitatif dengan menggunakan data primer yang dikumpulkan melalui survei. Subjek penelitian ditentukan dengan teknik random sampling, yaitu terhadap UKM mitra binaan PT. AP II Bandara St. Thaha Jambi. Teknik penarikan sampel tergolong probability sampling dengan menggunakan rumus Slovin $(\mathrm{e}=5 \%)$ diperoleh 156 responden. Pengumpulan data dilakukan dengan cara wawancara melalui kuesioner. Analisis data dilakukan dengan menggunakan analisis lintas. Hasil penelitian ini menunjukkan bahwa program kemitraan dalam memberikan bantuan kepada UKM masyarakat di Provinsi Jambi telah dilaksanakan dengan baik sesuai dengan amanat peraturan Menteri Negara BUMN, persepsi dan motivasi berpengaruh signifikan terhadap program kemitraan sedangkan hambatan tidak berpengaruh signifikan terhadap program kemitraan, keikutsertaan program kemitraan berpengaruh signifikan terhadap kesejahteraan UKM di Provinsi Jambi dan perubahan Tingkat kesejahteraan UKM berpengaruh signifikan terhadap Program Kemitraan.
\end{abstract}

Kata kunci: persepsi, motivasi, hambatan, program kemitraan dan kesejahteraan UKM

\footnotetext{
${ }^{1}$ Alamat Korespondensi:

Email: bobitkowanusutomo@yahoo.com
} 


\section{PENDAHULUAN}

Salah satu isu penting yang menjadi perhatian dalam dunia usaha hingga saat ini adalah CSR (Corporate Social Responsibility). Konsep tanggung jawab sosial perusahaan sendiri muncul sebagai akibat ketidakpercayaan masyarakat terhadap korporasi. Masyarakat menganggap korporasi sebagai pihak yang selalu mengeruk keuntungan tanpa memperdulikan kondisi masyarakat maupun lingkungan sekitarnya (Widjaja dan Pratama, 2008).

Dalam perkembangannya, dunia usaha semakin menyadari bahwa perusahaan tidak lagi dihadapkan pada tanggung jawab yang berpijak pada single bottom line, yaitu nilai perusahaan yang hanya direfleksikan dalam catatan keuangan saja, namun juga harus memperhatikan aspek sosial dan lingkungan. Menurut Elkington (1998) pada bukunya yang berjudul Cannibals With Forks: The Triple Bottom Line in 21st Century Business yang telah mengembangkan konsep triple bottom line dalam istilah economic prosperity, environmental quality, dan social justice. Apabila suatu perusahaan ingin mempertahankan kelangsungan hidupnya, maka perusahaan harus memperhatikan "3 P". Selain mengejar keuntungan (profit), perusahaan juga harus memperhatikan dan terlibat pada pemenuhan kesejahteraan masyarakat (people) serta turut berkontribusi aktif dalam menjaga kelestarian lingkungan (planet).

Implementasi CSR perusahaan pada dasarnya merupakan kontribusi aktif perusahaan dalam rangka ikut serta mewujudkan pembangunan berkelanjutan (sustainable development). Dimasukkannya konsep CSR perusahaan pada berbagai peraturan perundangundangan membuat konsep tanggung jawab sosial perusahaan bukan lagi "sekedar" kewajiban moral bagi perusahaan. Di Indonesia, kebijakanmengenaitanggung jawab sosial perusahaan diatur dalam Undang-Undang Nomor 40 Tahun 2007 tentang Perseroan Terbatas (UU PT) pada pasal 74 ayat (1-4), pasal 15 Undang-Undang Nomor 25 Tahun 2007 tentang Penanaman Modal (UU PM), dan Undang-Undang Nomor 19 Tahun 2003 tentang BUMN yang ditindaklanjuti dengan terbitnya Keputusan Menteri BUMN Nomor Kep236/MBU/2003 tentang Program Kemitraan Badan Usaha Milik Negara dengan Usaha Kecil dan Bina Lingkungan, sebagaimana telah beberapa kali diubah terakhir dengan Peraturan Menteri BUMN Nomor PER-08/MBU/2013.
Berdasarkan peraturan Menteri Badan Usaha Milik Negara (BUMN) nomor PER-08/MBU/2013 tentang Program Kemitraan Badan Usaha Milik Negara dengan Usaha Kecil dan Bina Lingkungan, BUMN wajib melaksanakan program kemitraan dan bina lingkungan. Hal ini dilaksanakan demi tercapainya tujuan pembangunan ekonomi kerakyatan oleh pemerintah. Kementrian BUMN mewajibkan perusahaan dan perum melaksanakan program kemitraan dan program bina lingkungan dan sekaligus membentuk unit khusus sebagaimana diatur dalam peraturan Menteri BUMN N0. PER-05/MBU/2007 yang diubah dengan No, PER08/MBU/2013. Atas dasar tersebut, PT. Angkasa Pura II (Persero) Tbk. sebagai BUMN membentuk unit khusus yang bertugas untuk melaksanakan Program Kemitraan dan Program Bina Lingkungan. Melalui kebijakan tersebut pemerintah mewajibkan BUMN untuk menyisihkan sebagian labanya untuk pemberdayaan masyarakat yang implementasinya ditindaklanjuti dengan dikeluarkannya Surat Edaran Menteri BUMN Nomor SE-433/MBU/2003 tentang Petunjuk Pelaksanaan Program Kemitraan Badan Usaha Milik Negara dengan Usaha Kecil dan Bina Lingkungan.

Bandara Sultan Thaha dalam hal ini adalah bagian dari PT. Angkasa Pura II (Persero) dalam tugasnya sehari-hari mengikuti jejak Angkasa Pura II (Persero) di JakartaCengkareng. Sehingga semua kebijaksanaan yang ada dikantor pusat dilakukan pula dikantor cabang baik segi kemitraan maupun bina lingkungannya. Adapun Visi dan Misi dari Program Kemitraan dan Bina Lingkungan sebagai berikut:

1. Visinya adalah menjadikan usaha kecil dan masyarakat sekitar bandara sebagai stakeholder maju bersama seiring dengan kemajuan perusahaan.

2. Misinya adalah melaksanakan kemitraan dengan usaha kecil hingga menjadi tangguh dan mandiri serta membantu pemberdayaan kondisi sosial mayarakat melalui dari bagian laba perusahaan dalam rangka meningkatkan pembangunan perekonomian nasional.

Program Kemitraan dan Bina Lingkungan (PKBL) merupakan bagian yang tidak terpisahkan dari organisasi perusahaan secara keseluruhan. Program kemitraan adalah usaha memberikan pinjaman lunak kepada mitra binaan atau masyarakat. Uang diperoleh dari hasil laba perusahaan sebanyak $2 \%$ dengan bunga pinjaman $6 \%$ pertahun atau $0,5 \%$ perbulannya dengan sistem flat. Program kemitraan bertujuan meningkatkan kemampuan usaha kecil mitra binaan agar menjadi 
tangguh dan mandiri sekaligus memberikan multiplier effect bagi peningkatan kesejahteraan masyarakat sekitar wilayah operasi Angkasa Pura II. Sasaran dari pelaksanaan program kemitraan ini adalah para pelaku UKM.

Usaha kecil dan menengah (UKM) merupakan kegiatan integral dunia usaha internasional yang mempunyai kedudukan, potensi dan peranan yang sangat penting serta strategis dalam mewujudkan pembangunan nasional pada umumnya dan tujuan pembangunan ekonomi kerakyatan pada khususnya sesuai dengan yang di cita-citakan oleh pemerintah. Demi meningkatkan dan menjaga sustainabilitas UKM di sekitar wilayah operasi PT. Angkasa Pura II khususnya di Bandara Sultan Thaha Jambi, kegiatan program kemitraan antara perusahaan dengan para pelaku UKM harus terealisasi, mengingat perusahaan bertanggung jawab untuk mengajak masyarakat di daerah sekitarnya untuk maju bersama perusahaan. Dengan adanya program kemitraan antara perusahaan dengan para pelaku UKM ini diharapkan kesejahteraan masyarakat dapat meningkat.

Usaha kecil dan menengah (UKM) mampu membuka lapangan kerja baru bagi masyarakat, mendorong kegiatan dan pertumbuhan ekonomi kerakyatan, terciptanya kesempatan untuk membuka usaha atau memperluas lapangan kerja serta pemerataan pembangunan dan pemberdayaan masyarakat. Tetapi dalam kenyataanya di Indonesia UKM sulit untuk berkembang. Hambatan-hambatan dalam UKM dapat di bagi menjadi dua yaitu Hambatan Eksternal dan Hambatan Internal. Berdasarkan hambatan yang telah dijabarkan di atas, bahwa hambatan yang memiliki pengaruh yang paling besar terhadap perkembangan UKM adalah hambatan dari segi permodalan. Menurut Wardoyo (2005), salah satu permasalahan utama UKM dalam mengembangkan usaha untuk menghadapi pasar global adalah karena lemahnya hal permodalan. Menurut Rosid (2008), Kurangnya modal adalah faktor utama yang paling berperan dan diperlukan dalam mengembangkan UKM. Sektor UKM ini mempunyai kendala dalam permodalan, dikarenakan dimulainya usaha dengan modal yang terbatas dan bersifat modal pribadidanrendahnyaaksesterhadaplembagakeuangan. Hambatan tersebut dapat diatasi dengan adanya sumber modal yang berasal dari Bank dan Non Bank.Sumber modal yang berasal dari Non Bank dalam penelitian ini adalah BUMN. Badan Usaha Milik Negara ini mempunyai banyak keunggulan dibandingkan dengan sumber modal yang berasal dari Bank. Sumber Modal yang berasal dari BUMN tersebut merupakan program CSR yang dikanal dengan istilah PKBL. Dalam setiap program yang dilaksanakan oleh BUMN perlu dinilai keefektifannya, agar dapat diketahui faktor-faktor yang menghambat dan mendukung, serta hasil yang telah dicapai dalam pelaksanaan program tersebut. Pada Tabel 1 menunjukkan target pinjaman yang harus diberikan kepada perserta program kemitraan mulai dari tahun 2011-2015.

Tabel 1. Target tahunan dan jumlah pinjaman perserta program kemitraan

\begin{tabular}{ccr}
\hline Tahun & Target Pinjaman & \multicolumn{1}{c}{ Jumlah Pinjaman } \\
\hline 2011 & - & $517.000 .000,00$ \\
2012 & $1.000 .000 .000,00$ & $1.465 .000 .000,00$ \\
2013 & $1.000 .000 .000,00$ & $892.500 .000,00$ \\
2014 & $1.000 .000 .000,00$ & $1.190 .000 .000,00$ \\
2015 & $1.000 .000 .000,00$ & $1.175 .000 .000,00$ \\
Jumlah & $4.000 .000 .000,00$ & $5.239 .500 .000,00$ \\
\hline
\end{tabular}

Pada tahun 2011 untuk target pinjaman yang diberikan kepada peserta program kemitraan masih belum ada karena kondisi PKBL di PT. AP II Bandara St. Thaha Jambi masih baru berjalan. Setelah itu, pada tahun 2012 hingga 2015 manajemen telah menetapkan bahwa target dana pinjaman yang telah dipersiapkan untuk program kemitraan tersebut adalaha sebesar 1 Miliyar. Dana pinjaman ini harus digunakan untuk membantu peserta program kemitraan dalam menjalankan UKM. Pada tahun 2010 PKBL belum mendapatkan peserta program kemitraan dikarenakan masih terdapat calon peserta yang belum memenuhi syarat dan masyarakat sekitar wilayah operasional PT. AP II Bandara St. Thaha Jambi juga belum secara menyebar dalam memperoleh informasi terkait adanya program kemitraan dari Tim PKBL. Oleh karena itu, Tim PKBL melakukan kegiatan pemberitahuan informasi terkait program kemitraan melalui kegiatan program bina lingkungan yang sebelumnya telah berjalan lebih dahulu pada tahun 2009. Sehingga informasi tentang program kemitraan yang di laksanakan oleh PT. AP II Bandara St. Thaha Jambi disampaikan kepada masyarakat dan tokoh-tokoh masyarakat untuk dapat bergabung menjadi peserta program atau mitra binaan UKM. Sehingga pada tahun 2011 menjadi awal tumbuh dan berkembangnya kemunculan peserta program kemitraan melalui pelaku UKM yang telah menjalankan usahanya selama minimal 1 (satu) tahun berjalan. Tidak hanya pemberian pinjaman yang diberikan bagi peserta program. Tetapi PT. Angkasa Pura II juga memberikan 
pelatihan, pemantauan (monitoring) atas penggunaan dana pinjaman tersebut.

Pada tahun 2012, PT Angkasa Pura II (Persero) telah menyelenggarakan pelatihan yang berlangsung diseluruh indonesia yang diikuti calon mitra binaan maupun mitra binaan, dan telah menyelenggrakan promosi/pameran dalam bentuk mengikuti sertakan dalam acara-acara pameran yang diselenggarakan didalam negeri maupun di luar negeri. Salah satu contoh acara yang telah dilakukan adalah pameran INACRAFT yang diselenggarakan dari tanggal 25-29 April 2012 bertempat di JCC yang diikuti oleh 8 Mitra Binaan dari Kantor Cabang Sultan Thaha Jambi, Kantor Cabang Halim Perdanakusuma Jakarta, Kantor Cabang Husein Sastranegara Bandung, Kantor Cabang Polonia Medan, Kantor Cabang Supadio Pontianak, Kantor Cabang Sultan Mahmud Badaruddin II Palembang, dan Kantor Cabang Utama Soekarno-Hatta. Unit PKBL di PT. AP II Khususnya di Bandara Sultan Thaha Jambi telah menindaklajuti penyaluran pinjaman bergulir dengan melakukan pemantauan (monitoring) atas penggunaan, pengelolaan maupun tingkat pengembaliannya agar seluruh mitra binaan agar berusaha dengan sungguhsungguh dan mengembalikan dana pinjaman tepat waktu.

Oleh karenaitu, peneliti sangat tertarik untuk melakukan penelitian di PKBL PT. AP II Bandara Sultan Thaha Jambi ini yang bertujuan menganalisis persepsi, motivasi dan hambatan dalam mengikuti program kemitraan; menganalisis pengaruh keikutsertaan program kemitraan terhadap kesejahteraan UKM di Provinsi Jambi; menganalisis tingkat kesejahteraan sebelum dan sesudah diberikan pinjaman dari program kemitraan serta untuk mengetahui apakah program kemitraan dalam memberikan bantuan kepada UKM masyarakat di Provinsi Jambi telah dilaksanakan dengan baik sesuai dengan amanat peraturan Menteri Negara BUMN.

\section{METODE PENELITIAN}

Dalam penelitian ini dilakukan terhadap UKM terpilih dari Unit PKBL di PT. AP II Bandara Sulta Thaha Jambi. Adapun waktu pengambilan data dilakukan selama \pm 2 bulan yaitu dimulai pada bulan 1 Juli-31 Agustus 2016
Data yang digunakan dalam penelitian ini adalah data primer yang dikumpulkan melalui survei terhadap responden dari beberapa sektor usaha UKM di Provinsi Jambi dengan sumber data yang berasal dari populasi peserta UKM Mitra Binaan unit PKBL PT. AP II Bandara Sultan Thaha Jambi yang telah bergabung lebih dari 1 (satu) tahun. Data responden dari peserta itu sendiri diambil mulai dari tahun 2011 sampai dengan tahun 2015 yang berjumlah sebanyak 255 orang.

Pendekatan penelitian ini menggunakan pendekatan deskriptif dan kuantitatif dengan menggunakan data primer yang dikumpulkan melalui survei dengan metode yang digunakan adalah random sampling. Teknik penarikan contoh yang digunakan tergolong dalam probability sampling, yaitu pengambilan sampel yang setiap anggota populasi memiliki kesempatan yang sama untuk terpilih. Teknik penarikan contoh dalam penelitian ini menggunakan rumus Slovin dalam Riduwan (2004) :

$$
n=\frac{N}{1+N e^{2}}
$$

Keterangan: N (Jumlah populasi mitra binaan UKM di Provinsi Jambi); e (Sampling error).

Pendekatan deskriptif digunakan untuk memberikan gambaran mengenai persepsi, motivasi dan hambatan terhadap keikutsertaan program kemitraan dan kesejahteraan UKM di Provinsi Jambi yang menjadi mitra binaan PKBL PT. AP II Bandara Sultan Thaha Jambi. Pendekatan kuantitatif digunakan untuk penelitian yang analisisnya lebih fokus pada data-data numerikal (angka) yang diolah dengan menggunakan metode statistika. Dengan menggunakan pendekatan ini, maka akan diperoleh signifikansi hubungan antar variabel yang diteliti.

Berdasarkan jumlah populasi mitra binaan UKM di Provinsi Jambi sebanyak 255 orang yang telah bergabung lebih dari 1 (satu) tahun menjadi UKM Mitra Binaan PKBL PT. AP II Bandara Sultan Thaha Jambi sejak tahun 2011 sampai dengan 2015 serta berada di Provinsi Jambi. Maka diambil ukuran sampel menggunakan rumus Slovin dengan e $=5 \%$. Sehingga, ukuran sampel mitra binaan UKM di Provinsi Jambi yang diperoleh adalah 156 responden. UKM tersebut terdiri dari beberapa sektor usaha antara lain, adalah sektor industri, jasa, perdagangan, perikanan, pertanian dan peternakan. 
Dalam penelitian ini dilakukan analisis terhadap responden sebanyak 156 orang dan akan dipilih secara acak menggunakan fungsi random yang terdapat pada aplikasi Excel sehingga peluang setiap anggota mitra binaan UKM di Provinsi Jambi terpilih sama besar mulai dari anggota mitra yang memiliki usaha pada sektor industri hingga yang memiliki usaha pada sektor peternakan.

Perangkat alat dan cara dalam memperoleh dan mengumpulkan data yang berkaitan dengan proses pengembangan PKBL dalam meningkatkan kesejahteraan UKM masyarakat disekitar lingkungan perusahaan di Provinsi Jambi adalah dengan menggunakan angket kuesioner yang terdiri dari pertanyaan - pertanyaan yang mengarah kepada atributatribut yang berhubungan dengan program kemitraan untuk UKM. Kemudian dibagi kedalam dua variabel yakni variabel eksogen (bebas) dan variabel endogen (terikat).

Berikut adalah klasifikasi dari masing-masing variabel yang digunakan dalam penelitian tersebut:

\section{a) Variabel eksogen (bebas)}

Persepsi terhadap bantuan; UKM bisa menjadi mandiri, informasi program kemitraan mudah diperoleh, manfaat program dapat dirasakan UKM, meningkatkan kesejahteraan UKM, pendaftaran dan administrasi tidak terlalu sulit, pembayaran mudah, syarat mudah, pelayanan sangat baik, laporan keuangan mudah, mendapatkan pelatihan, dapat mengikuti event pemasaran, serta dengan adanya jaminan UKM lebih bertanggung jawab dalam pengembalian pinjaman.

Motivasi menerima bantuan; ada peluang mendapat pelatihan, mengikuti event pemasaran secara nasional, pembayaran cicilan tidak memberatkan, syarat bergabung mudah dan cepat, mendapatkan bimbingan dan pelatihan berkala, membantu perekonomian, menambah aset, menaikkan status sosial, menambah aset, dan bias mengembangkan usaha lainnya.

Hambatan yang dihadapi dalam UKM; administrasi pengembalian tidak rapih, tidak ada pendampingan dalam promosi usaha, tidak mendapat dukungan dari pihak keluarga, tidak paham cara mengelola pinjaman, lingkungan usaha tidak ramai dan terlalu banyak persaingan

\section{b) Variabel endogen (terikat)}

Keikutsertaan program kemitraan; menjadi peserta program kemitraan satu tahun mendatang, mengikuti pelatihan dan program pembinaan, membayar angsuran tepat waktu dan mengikuti acara pameran nasional.

Kesejahteraan UKM mitra binaan; dapat diukur melalui selisih tingkat pendapatan yang diperoleh sebelum mendapatkan bantuan program dengan setelah diberikan bantuan program kemitraan, dapat memenuhi pengeluaran rumah tangga untuk pangan dengan nonpangan, dan fasilitas rumah tangga menjadi lebih baik. Setelah data terkumpul, selanjutnya dilakukan pengolahan data dengan menggunkan metode kualitatif dan kuantitatif. Metode analisis yang dipakai dalam mengolah data hasil kuesioner dalam penelitian ini adalah menggunakan Skala Likert yang dimodifikasi menjadi lima skala pengukuran yang merupakan respon persetujuan terhadap suatu pernyataan.

Menurut Kinear dalam Umar (1998), Skala Likert berhubungan dengan pernyataan tentang sikap seseorang terhadap sesuatu, seperti setuju-tidak setuju, suka-tidak suka dan sebagainya. Dalam skala ini responden diminta mengisi pendapatnya mengenai pernyataan dalam bentuk kuesioner. Kemudian hasilnya dikuantitatifkan ke dalam bentuk skor dari masing-masing dengan acuan, yaitu Sangat setuju (SS) (5); setuju (S) (4); Ragu-ragu (R) (3); tidak setuju (TS) (2); dan sangat tidak setuju (STS) (1). Pengujian validitas dan reliabilitas dilakukan pada saat ujicoba kuesioner terhadap 40 responden dengan metode uji korelasi dan cronbach alpha. Uji validitas dilakukan untuk mengetahui kemampuan pernyataanpernyataan yang terdapat dalam kuesioner melakukan fungsinya sebagai alat ukur. Uji validitas dilakukan dengan melihat korelasi antara nilai masing-masing pernyataan dengan jumlah dari nilai-nilai pernyataan setiap variabel latennya. Nilai koefisien korelasi yang diperoleh positif dan nilainya lebih besar dari nilai $r$ tabel (taraf nyata, n), menunjukkan bahwa instrumen yang digunakan valid (Tika, 2006). Nilai $r$ tabel untuk taraf nyata $5 \%$ dan ukuran contoh 40 adalah 0,312 . Uji reliabilitas digunakan untuk mengetahui konsistensi dan keterandalan kuesioner sebagai alat ukur. Nilai koefisien reliabilitas lebih besar atau sama dengan 0.6 menunjukkan bahwa instrumen reliabel (Idrus, 2009). 
Selanjutnya, dilakukan Analisis lintas untuk menilai kontribusi langsung dan tidak langsung suatu variabel, dimana beberapa variabel sebagai penyebab terhadap variabel lain yang ditetapkan sebagai akibat (Dillon dan Goldstein, 1984; Joreskog dan Sorbom, 1993). Terdapat dua macam variabel dalam analisis lintas yaitu variabel yang tidak dipengaruhi oleh variabel lain dalam sistem (variabel penyebab) disebut variabel eksogen dan variabel yang dipengaruhi oleh variabel lain (variabel akibat) disebut variabel endogen (Gall dan Borg, 2003).

Beberapa asumsi dalam analisis lintas yang harus terpenuhi adalah sebagai berikut (Dillon dan Goldstein, 1984): 1) Hubungan antar variabel pada analisis lintas adalah linier; 2) Sisaan tidak berkorelasi satu sama lain; 3) Hanya terdapat aliran/hubungan kausal satu arah; 4) Variabel minimal diukur dalam skala interval; 5) Variabel yang diamati diasumsikan diukur dengan benar; 6) Model lintasan yang dibuat dispesifikasikan dengan tepat berdasarkan teori.

Pola hubungan antar variabel ditampilkan dalam diagram lintas pada Gambar 1, yang penggambarannya memiliki beberapa makna (Johnson dan Wichern, 1998): 1) Garis panah lurus satu arah menunjukkan pengaruh langsung dari variable penyebab ke variabel terikat; 2) Garis panah lurus satu arah menghubungkan sisaan dengan masing-masing; 3) variabel terikatnya;
4) Garis panah berbentuk kurva dan putus-putus dua arah menunjukkan adanya; 5) korelasi antar variabel penyebab.

Pengujian Hipotesis dalam penelitian ini menggunakan Uji F digunakan untuk pengujian signifikansi koefisien lintas secara simultan dengan statistik uji $\mathrm{F}$ dengan hipotesis sebagai berikut (Kusnendi, 2008). Uji t digunakan untuk melakukan uji signifikansi masingmasing koefisien lintas dengan hipotesis sebagai berikut (Kusnendi, 2008). Uji Kebaikan Model diukur menggunakan R-Square (Koefisien Determinasi) variabel endogen. R-Square gabungan untuk model struktural digunakan untuk mengukur kebaikan nilai observasi yang dihasilkan oleh model dan estimasi parameternya. Perhitungan R-Square gabungan dilakukan dengan rumus (Dillon dan Goldstein, 1984).

Pada Gambar 2 menunjukkan kerangka penelitian pengaruh dari persepsi motivasi dan hambatan terhadap keikutsertaan Program Kemitraan dari PKBL PT. Angkasa Pura II Bandara Sultan Thaha Jambi dengan objek penelitiannya adalah UKM Mitraa Binaan PKBL itu sendiri yang terdapat di Provinsi Jambi. Setelah itu akan dilihat pengaruhnya terhadap tingkat kesejahteraan UKM tersebut dengan indikator tingkat pendapatan pada saat sebelum dan sesudah memperoleh pinjaman atau bantuan dari program kemitraan yang diberikan oleh PKBL PT. AP II Provinsi Jambi.

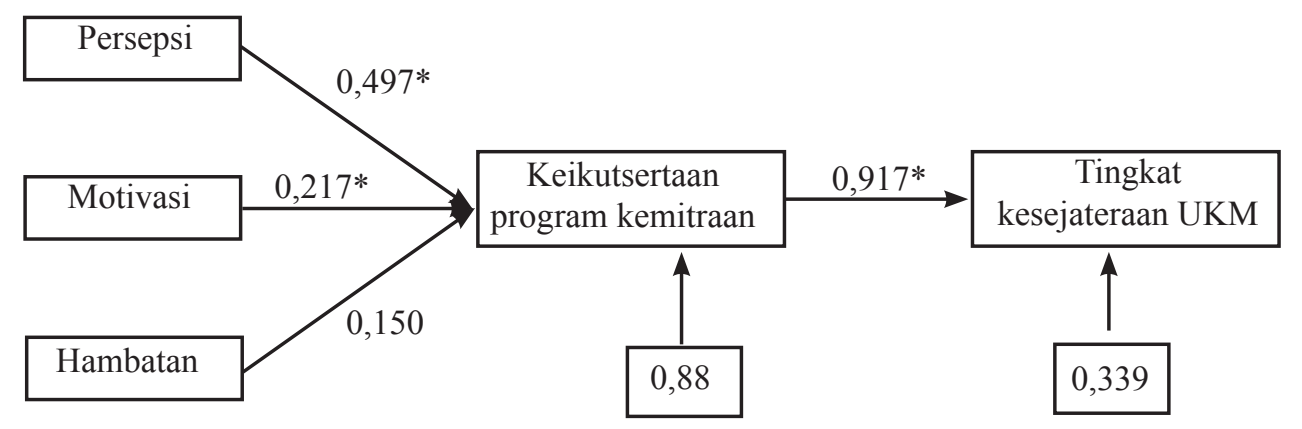

Gambar 1. Diagram lintas jalur (*signifikan pada taraf nyata 5\%)

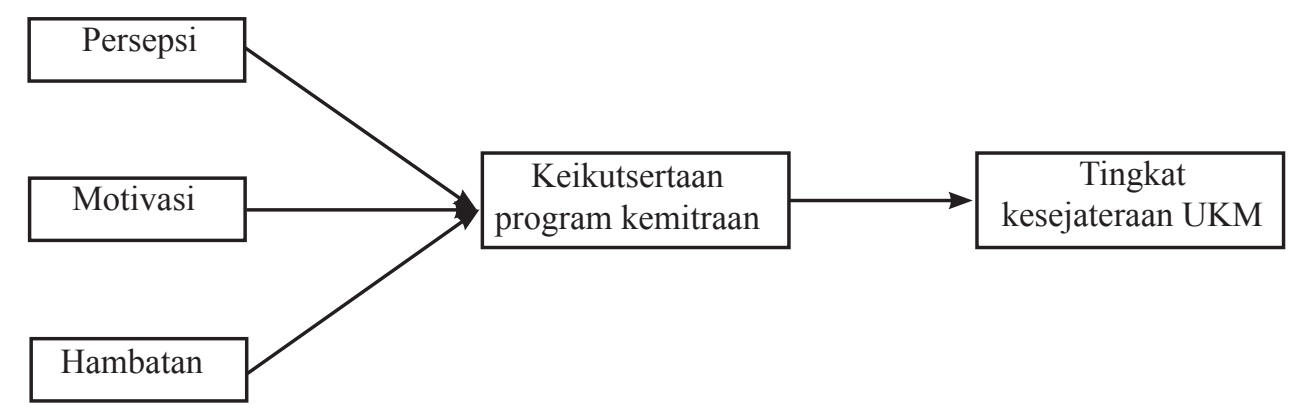

Gambar 2. Kerangka pemikiran penelitian 


\section{HASIL}

\section{Karakteristik demografi responden}

Responden dalam penelitian ini adalah responden yang telah menjadi mitra binaan UKM PT. AP II Bandara Sultan Thaha di Provinsi Jambi selama lebih dari 1 Tahun. Total responden yang memenuhi kriteria sebesar 156 responden. Karakterisitik demografi responden yang digunakan dalam penelitian ini terbagi menjadi delapan kriteria meliputi usia, jenis kelamin, tingkat pendidikan, pendapatan, jumlah anggota keluarga, pekerjaan pasangan, jenis usaha, dan tahun bergabung dengan Program Kemitraan di Provinsi Jambi. Karakteristik demografi responden selengkapnya pada Tabel 2.

\section{Persepsi, Motivasi dan Hambatan terhadap Keikutsertaan dan Tingkat Kesejahteraan Peserta Program Kemitraan}

Persepsi

Berdasarkan Tabel 3 dapat dilihat kecenderungan responden dalam menjawab pertanyaan yang diajukan. total yang dihasilkan oleh indikator pernyataan pada variabel Persepsi minimal 521 dan maksimal 660. Jawaban tertinggi ada pada pernyataan X1.1 (Program Kemitraan bertujuan meningkatkan kemampuan usaha kecil mitra binaan agar menjadi mandiri) dengan total skor 660 dengan nilai top two boxes sebesar 100\%. Pernyataan yang menghasilkan total terkecil sebesar 521 dan nilai top two boxes $27 \%$, yaitu pernyataan X1.9 (Laporan keuangan Mudah).

\section{Motivasi}

Berdasarkan Tabel 4 dapat dilihat kecenderungan responden dalam menjawab pertanyaan yang diajukan. total yang dihasilkan oleh indikator pernyataan pada variabel Motivasi minimal 769 dan maksimal 776. Jawaban tertinggi ada pada pernyataan X2.1 (Saya mengikuti Program Kemitraan dan Kesejahteraan UKM di Provinsi Jambi karena beberapa hal) dengan total skor 776 dengan nilai top two boxes sebesar 100\%. Pernyataan yang menghasilkan total terkecil sebesar 769 dan nilai top two boxes $100 \%$ yaitu pernyataan X2.11 (Ingin menambah pengalaman wirausaha).
Tabel 2. Karakteristik demografi responden

\begin{tabular}{|c|c|c|c|}
\hline Karateristik & Kriteria Responden & Jumlah & $(\%)$ \\
\hline \multirow[t]{9}{*}{ Usia Responden } & 20 s.d 24 tahun & 3 & 2 \\
\hline & 25 s.d 29 tahun & 17 & 11 \\
\hline & 30 s.d 34 tahun & 21 & 13 \\
\hline & 35 s.d 39 tahun & 52 & 33 \\
\hline & 40 s.d 44 tahun & 28 & 18 \\
\hline & 45 s.d 49 tahun & 11 & 7 \\
\hline & 50 s.d 54 tahun & 21 & 13 \\
\hline & 55 s.d 59 tahun & 0 & 0 \\
\hline & 60 s.d 64 tahun & 3 & 2 \\
\hline \multirow{2}{*}{ Jenis Kelamin } & Laki-Laki & 95 & 61 \\
\hline & Perempuan & 61 & 39 \\
\hline \multirow{7}{*}{$\begin{array}{l}\text { Tingkat } \\
\text { Pendidikan }\end{array}$} & SD & 9 & 7 \\
\hline & SMP & 47 & 30 \\
\hline & STM & 16 & 10 \\
\hline & SMA & 44 & 28 \\
\hline & D3 & 10 & 6 \\
\hline & PGA & 3 & 2 \\
\hline & S1 & 27 & 17 \\
\hline \multirow{9}{*}{$\begin{array}{l}\text { Jenis Pekerjaan } \\
\text { Pasangan }\end{array}$} & Bangunan & 2 & 1,3 \\
\hline & Dagang & 11 & 7,1 \\
\hline & Guru & 3 & 2,6 \\
\hline & Jaga Toko & 11 & 7,1 \\
\hline & PNS & 5 & 3,2 \\
\hline & Swasta & 51 & 29,5 \\
\hline & Telkom & 4 & 2,6 \\
\hline & URT & 63 & 40,4 \\
\hline & Wiraswasta & 5 & 3,2 \\
\hline \multirow[t]{6}{*}{ Sektor Usaha } & 1. Industri & 22 & 14,1 \\
\hline & 2. Jasa & 38 & 24,4 \\
\hline & 3. Perdagangan & 88 & 56,4 \\
\hline & 4. Perikanan & 2 & 1,3 \\
\hline & 5. Pertanian & 1 & 0,6 \\
\hline & 6. Peternakan & 5 & 3,2 \\
\hline \multirow[t]{3}{*}{$\begin{array}{l}\text { Tingkat } \\
\text { Pendapatan }\end{array}$} & $\begin{array}{l}\text { Rp1.000.000 s.d } \\
\text { Rp2.500.000 }\end{array}$ & 19 & 12 \\
\hline & $\begin{array}{l}\text { Rp2.500.001 s.d } \\
\text { Rp3.500.000 }\end{array}$ & 44 & 28 \\
\hline & $\begin{array}{l}\text { Rp3.500.001 s.d } \\
\text { Rp5.000.000 }\end{array}$ & 93 & 60 \\
\hline \multirow{6}{*}{$\begin{array}{l}\text { Jumlah Anggota } \\
\text { Keluarga }\end{array}$} & 0 & 4 & 3 \\
\hline & 1 & 26 & 17 \\
\hline & 2 & 87 & 56 \\
\hline & 3 & 32 & 21 \\
\hline & 4 & 7 & 4 \\
\hline & Jumlah & 156 & 100 \\
\hline
\end{tabular}


Tabel 3. Persepsi terhadap bantuan

\begin{tabular}{|c|c|c|c|c|c|c|c|}
\hline \multirow{2}{*}{ Pernyataan } & \multicolumn{5}{|c|}{ Persentase (\%) } & \multirow{2}{*}{ Total } & \multirow{2}{*}{$\begin{array}{l}\text { Rata- } \\
\text { rata }\end{array}$} \\
\hline & STS & TS & $\mathrm{R}$ & $\mathrm{S}$ & SS & & \\
\hline Meningkatkan kemampuan UKM & 0 & 0 & 0 & 77 & 23 & 660 & 4,23 \\
\hline Informasi mudah diperoleh & 0 & 0 & 0 & 97 & 3 & 629 & 4,03 \\
\hline Cara daftar dan administrasi tidak sulit & 0 & 0 & 1 & 86 & 13 & 644 & 4,13 \\
\hline Cara pembayaran mudah & 0 & 0 & 0 & 83 & 17 & 650 & 4,17 \\
\hline Syarat bergabung tidak sulit & 0 & 0 & 0 & 97 & 3 & 629 & 4,03 \\
\hline Pelayanan Tim PKBL sangat baik & 0 & 0 & 0 & 86 & 14 & 646 & 4,14 \\
\hline Laporan keuangan mudah & 0 & 0 & 72 & 21 & 6 & 521 & 3,34 \\
\hline Jaminan agar UKM bertanggungjawab dalam pengembalian pinjaman & 0 & 0 & 0 & 96 & 4 & 630 & 4,04 \\
\hline
\end{tabular}

Tabel 4. Motivasi menerima bantuan

\begin{tabular}{|c|c|c|c|c|c|c|c|}
\hline \multirow{2}{*}{ Pernyataan } & \multicolumn{5}{|c|}{ Persentase (\%) } & \multirow{2}{*}{ Total } & \multirow{2}{*}{$\begin{array}{l}\text { Rata- } \\
\text { rata }\end{array}$} \\
\hline & STS & $\mathrm{TS}$ & $\mathrm{R}$ & $\mathrm{S}$ & SS & & \\
\hline Pelatihan meningkatkan keterampilan usaha & 0 & 0 & 0 & 3 & 97 & 776 & 4,97 \\
\hline Menambah aset & 0 & 0 & 0 & 6 & 94 & 771 & 4,94 \\
\hline Menaikkan status sosial & 0 & 0 & 0 & 6 & 94 & 771 & 4,94 \\
\hline Menambah pengalaman & 0 & 0 & 0 & 6 & 94 & 770 & 4,94 \\
\hline Pengembangan Usaha & 0 & 0 & 0 & 7 & 93 & 769 & 4,93 \\
\hline
\end{tabular}

Tabel 5. Hambatan yang dihadapi

\begin{tabular}{lcccccccc}
\hline & \multirow{2}{*}{ Pernyataan } & \multicolumn{4}{c}{ Persentase (\%) } & \multirow{2}{*}{ Total } & $\begin{array}{c}\text { Rata- } \\
\text { rata }\end{array}$ \\
\cline { 2 - 7 } & STS & TS & R & S & SS & & & \\
& Administrasi setoran tidak rapih & 0 & 2 & 0 & 98 & 0 & 618 & 3,96 \\
Tidak ada pendampingan & 7 & 92 & 1 & 0 & 0 & 303 & 1,94 \\
Keluarga tidak mendukung & 10 & 90 & 0 & 0 & 0 & 296 & 1,90 \\
Lingkungan usaha tidak ramai & 10 & 90 & 0 & 0 & 0 & 296 & 1,90 \\
Banyak persaingan & 7 & 93 & 0 & 0 & 0 & 301 & 1,93 \\
\hline
\end{tabular}

\section{Hambatan}

Berdasarkan Tabel 5 dapat dilihat kecenderungan responden dalam menjawab pertanyaan yang diajukan. total yang dihasilkan oleh indikator pernyataan pada variabel Hambatan minimal 296 dan maksimal 618. Jawaban tertinggi ada pada pernyataan X3.1 (Admisnistrasi pengembalian uang setoran tidak rapih) dengan total skor 618 dengan nilai top two boxes sebesar 98\%. Pernyataan yang menghasilkan total terkecil sebesar 296dan nilai top two boxes $0 \%$ yaitu pernyataan X3.3 dan X3.5 (Tidak mendapat dukungan dari keluarga untuk mengikuti program kemitraan dan Lingkungan usaha tidak terlalu ramai).

\section{Keikutsertaan Program Kemitraan}

Berdasarkan Tabel 6 dapat dilihat kecenderungan responden dalam menjawab pertanyaan yang diajukan. total yang dihasilkan oleh indikator pernyataan pada variabel Keikutsertaan program minimal 301 dan maksimal 766. Jawaban tertinggi ada pada pernyataan Y1.1 dan Y1.2 (Saya akan tetap menjadi peserta program kemitraan untuk satu tahun mendatang dan Saya rajin mengikuti pelatihan secara rutin) dengan total skor 766 dengan nilai top two boxes sebesar $100 \%$. Pernyataan yang menghasilkan total terkecil sebesar 301 dan nilai top two boxes $1 \%$ yaitu pernyataan Y1.5 (Saya selalu mengikuti acara pameran secara nasional). 
Tabel 6. Keikutsertaan program kemitraan

\begin{tabular}{|c|c|c|c|c|c|c|c|}
\hline \multirow{2}{*}{ Pernyataan } & \multicolumn{5}{|c|}{ Persentase $(\%)$} & \multirow{2}{*}{ Total } & \multirow{2}{*}{$\begin{array}{c}\text { Rata- } \\
\text { rata }\end{array}$} \\
\hline & STS & TS & $\mathrm{R}$ & $\mathrm{S}$ & SS & & \\
\hline Tetap menjadi peserta PK setahun mendatang & 0 & 0 & 0 & 9 & 91 & 766 & 4,91 \\
\hline Rajin ikut pelatihan & 0 & 0 & 0 & 9 & 91 & 766 & 4,91 \\
\hline Rajin ikut pembinaan & 0 & 0 & 2 & 13 & 85 & 754 & 4,83 \\
\hline Membayar angsuran tepat waktu & 0 & 0 & 0 & 13 & 87 & 759 & 4,87 \\
\hline Ikut acara pameran nasional & 9 & 9 & 0 & 0 & 1 & 301 & 1,93 \\
\hline
\end{tabular}

Tabel 7, Kesejahteraan UKM

\begin{tabular}{lcccccccc}
\hline \multicolumn{1}{c}{ Pernyataan } & \multicolumn{4}{c}{ Persentase (\%) } & \multirow{2}{*}{ Total } & $\begin{array}{c}\text { Rata- } \\
\text { rata }\end{array}$ \\
\cline { 2 - 7 } & STS & TS & R & S & SS & & & \\
\hline Pendapatan meningkat setelah ikut PK & 0 & 0 & 0 & 12 & 88 & 761 & 4,88 \\
Pendapatan memenuhi pengeluaran rumah tangga & 0 & 0 & 4 & 16 & 79 & 741 & 4,75 \\
Kondisi fasilitas rumah lebih baik & 0 & 0 & 3 & 15 & 81 & 746 & 4,78 \\
\hline
\end{tabular}

Kesejahteraan UKM

Berdasarkan Tabel 7 dapat dilihat kecenderungan responden dalam menjawab pertanyaan yang diajukan. total yang dihasilkan oleh indikator pernyataan pada variabel Kesejahteraan UKM minimal 741 dan maksimal 761.

Jawaban tertinggiadapadapernyataan Y2.1 (Pendapatan keluarga meningkat setelah mengikuti program kemitraan) dengan total skor 761 dengan nilai top two boxes sebesar $100 \%$. Pernyataan yang menghasilkan total terkecil sebesar 741dan nilai top two boxes $95 \%$ yaitu pernyataan Y2.2 (Pendapatan UKM mitra binaan dapat memenuhi pengeluaran rumah tangga untuk pangan dengan non-pangan).

\section{Selisih Tingkat Pendapatan Sebelum dan Sesudah Mengikuti Program Kemitraan}

Hasil Uji-t untuk melihat perbedaan antara pendapatan sebelum mengikuti program kemitraan dan setelah mengikuti program, didapatkan bahwa terdapat signifikansi nilai-p (0.000). Hal ini menunjukkan bahwa terdapat perbedaan rata-rata pendapatan sebelum program (2,42 juta Rupiah) dengan rata-rata pendapatan setelah mengkuti program (3.337 juta Rupiah)

\section{Faktor - faktor yang Memengaruhi Keikutsertaan dan Tingkat Kesejahteraan}

Sebelum melakukan analisis lintas, terlebih dahulu dilakukan uji linieritas pada setiap persamaan substruktural. Terdapat dua persamaan substruktural yang dibangun pada hipotesis awal dengan diagram lintas seperti yang tertera pada Gambar 1. Ringkasan uji linieritas pada kedua persamaan substruktural dapat dilihat pada Lampiran 4. Uji linieritas pada persamaan substruktural satu (Keikutsertaan) dan dua (Kesejahteraan) memberikan hasil bahwa semua variabel eksogen memiliki hubungan linier dengan variabel endogen. Gambar 5 menjelaskan tentang diagram lintas jalur dari variabel-variabel penelitian tekait persepsi, motivasi, hambatan, keikutsertaan program kemitraan dan tingkat kesejahteraan UKM

Statistik uji F pada persamaan sub struktural satu satu maupun persamaan sub struktural dua memberikan hasil bahwa minimal terdapat satu variabel eksogen yang berpengaruh terhadap variabel endogen Keikutsertaan (Y1) dan variabel endogen Kesejahteraan (Y2) pada taraf nyata $5 \%$.

Uji signifikansi masing-masing koefisien lintas dengan statistik uji t pada persamaan sub struktural satu memberikan hasil terdapat satu variabel eksogen yang tidak berpengaruh terhadap Keikutsertaan (Y1) pada taraf nyata 5\% yaitu variabel Hambatan (X3). Hal ini dikarenakan administrasi yang berjalan di PKBL PT. AP II Provinsi Jambi berjalan dengan rapih, pendampingan dari Tim PKBL sangat membantu peserta UKM Mitra binaan dalam menyelesaikan masalah atau kesulitan yang dihadapi serta tata cara pengelolaan dana pinjaman dalam membantu pengembangan usaha dipahami dengan baik oleh peserta UKM tersebut. Penelitian Suistyo dan Diatama (2011) terkait Program Kemitraan dengan objek penelitiannya adalah UKM kota Semarang. Dari hasil penelitiannya menunjukkan 
bahwa kemitraan BUMN dan UKM dalam faktor internal sudah cukup baik, semuanya berkorelasi positif terhadap peningkatan kapabilitas inovasi serta kinerja (kecuali pengetahun memahami konsumen dan keterampilan administrasi keuangan dan akutansi.

Hambatan-hambatan dalam UKM dapat dibagi menjadi dua, yaitu hambatan eksternal dan hambatan internal. Berdasarkan hambatan yang telah dijabarkan menunjukkan bahwa hambatan tidak berpengaruh terhadap keikutsertaan. Tetapi yang memiliki pengaruh paling besar terhadap perkembangan UKM adalah hambatan dari segi permodalan. Hambatan lainnya yang berasal dari intenal seperti kurangnya dukungan dari pihak keluarga dalam mengikuti progam kemitraan, kurangnya pengetahuan dan keterampilan dalam mengelola dana pinjaman yang diberikan. Sebelum mendapatkan program kemitraan, usaha masih ikut dengan orang (terikat dengan orang lain), produksinya juga masih berskala kecil karena dananya juga terbatas, namun saat ini produksi menjadi semakin berkembang karena telah mendapatkan pinjaman modal melalui program kemitraan PT. AP II Bandara Sultan Thaha Jambi di Provinsi Jambi. Sedangkan hambatan yang berasal dari eksternal diantaranya adalah lingkungan usaha disekitar tidak terlalu ramai dan kesulitan dalam memperoleh pendampingan dalam melakukan promosi atau inovasi produk. Cara penjualan atau pemasaran produk yang sebelumnya masih melalui penampung/ tengkulak dengan mengambil hasil produksi untuk dijual kembali, sekarang telah banyak cara untuk memasarkan hasil produksi umumnya home industry dari beberapa sektor usaha perdagangan, peternakan, perikanan dan lainnya sudah bisa diakses melalui beberapa media sosial atau internet agar lebih dikenal oleh khalayak umum sehingga diharapkan akan dapat memudahkan proses pemasaran dan penjualan produk. Selain itu, hambatan yang sering terjadi secara umum ketika telah mendapatkan bantuan dari Program Kemitraan adalah banyaknya Mitra Binaan yang macet dalam ketepatan waktu pembayaran kembali pokok dan jasa administrasi pinjaman. Terdapat beberapa kategori keterlambatan dalam pembayaran piutang, yaitu Pembayaran terlambat selama 1 hari atau lebih sejak tanggal jatuh tempo tergolong kurang lancar; Pembayaran terlambat selama 1 bulan atau lebih sejak tanggal jatuh tempo tergolong tidak lancar; Pembayaran terlambat selama lebih dari 3 bulan sejak tanggal jatuh tempo tergolongan macet.
PKBL PT. AP II Bandara Sultan Thaha Jambi dalam mengatasi hambatan diatas adalah dengan cara memberikan pendampingan dari Tim PKBL untuk dapat membantu peserta UKM Mitra binaan dalam menyelesaikan masalah atau kesulitan yang dihadapi. Kemudian memberikan informasi dan penjelasan terhadap tata cara pengelolaan dari dana pinjaman yang telah diberikan dalam membantu pengembangan usaha sehingga dapat dipahami dengan baik oleh peserta UKM tersebut.

Uji signifikansi koefisien lintas pada persamaan sub struktural dua dengan statistik uji t memberikan hasil variabel eksogen Keikutsertaan (Y1) yang berpengaruh terhadap Kesejahteraan (Y2) pada taraf nyata 5\%.

Asumsi sisaan saling bebas dari persamaan sub struktural satu dan persamaan sub struktural dua dari model terpenuhi karena hasil tes autokorelasi dengan Uji Durbin Watson menunjukkan nilai-p $>0.05$, artinya sisaan saling bebas. Sisaan yang saling bebas menunjukkan bahwa responden mitra binaan UKM PT. AP II Bandara Sultan Thaha di Provinsi Jambi tidak memengaruhi satu sama lain dalam menjawab instrumen kuesioner yang diberikan. Keragaman data (R2) model gabungan adalah sebesar 0.976, artinya keragaman data yang dapat dijelaskan oleh model adalah sebesar $97.6 \%$, sedangkan sisanya sebesar 2.4\% dijelaskan oleh faktor lain yang tidak dimasukkan ke dalam model.

Besarnya pengaruh langsung dan pengaruh tidak langsung antar variabel dihitung dari model. Besarnya pengaruh langsung dan pengaruh tidak langsung terhadap masing-masing variabel endogen (terikat) yaitu Keikutsertaan (Y1) dan Kesejahteraan (Y2) dapat dilihat pada Tabel 9 yang menunjukkan tentang hasil penelitian terkait besar pengaruh langsung dan pengaruh tidak langsung terhadap keikutsertaan dan kesejahteraan pada model.

Persepsi UKM mitra binaan PKBL di PT. AP II Bandara Sultan Thaha Jambi yang tertanam baik yang dibangun oleh kemudahan akses informasi program kemitraan, tata cara birokrasi dalam mengurus program kemitraan, serta pelayanan yang baik dari Tim PKBL AP II Bandara St. Thaha Jambi kepada UKM mitra binaan, dominan memengaruhi pelaku UKM dalam keputusannya untuk mengikuti program kemitraan UKM yang diselenggarakan oleh AP II Bandara St. Thaha Jambi. 
Persepsi dari UKM mitra binaan akan program kemitraan yang dilaksanakan oleh PKBL PT. AP II Jambi ini memang beragam. Hal ini dikemukakan oleh Sutisna (2001) bahwa persepsi dari setiap orang terhadap suatu obyek akan berbeda-beda dikarenkan persepsi mempunyai sifat subyektif. Kotler (2000) juga menjelaskan bahwa persepsi sebagai proses bagaimana seseorang menyeleksi, mengatur dan menginterpretasikan masukan-masukan informasi untuk menciptakan gambaran keseluruhan yang berarti.

Seiring dengan pertumbuhan dan perkembangan ekonomi masyarakat yang sangat dinamis, pedoman yang telah diterbitkan melalui peraturan pemerintah terkait PKBL ternyata belum dapat memenuhi harapan masyarakat pelaku usaha kecil dan kebutuhan pengelola dalam pelaksanaan program. Atas dasar pertimbangan tersebut maka Pemerintah cq. Kementrian BUMN memandang perlu menertibkan keputusan Menteri BUMN Nomor KEP. 236/MBU/2003 tanggal 17 Juni 2003 tentang Program Kemitraan BUMN dengan Usaha Kecil dan Program Bina Lingkungan (PKBL) yang mengatur kemitraan BUMN dengan Usaha Kecil yang lebih komprehensif dan sesuai dengan perkembangan ekonomi dan kondisi lingkungan sosial masyarakat sekitar BUMN.

1. BUMN wajib melaksanakan Program Kemitraan dan Program Bina Lingkungan dengan memenuhi ketentuan-ketentuan yang diatur dalam Keputusan ini.

2. Persero terbuka dapat melaksanakan Program KemitraandanBinaLingkungan dengan berpedoman pada keputusan ini yang ditetapkan berdasarkan keputusan rapat umum pemegang saham (RUPS).

Berdasarkan hal tersebut PT. AP II Bandara Sultan Thaha Jambi memberikan kemudahan kepada masyarakat provinsi Jambi dalam memperoleh akses informasi terkait program kemitraan khususnya untuk calon UKM mitra binaan yang diperoleh dari Tim PKBL. Faktor motivasi (koefisien jalur $=0,217$ ) UKM mitra binaan menjadi faktor lain dari pengambilan keputusan pelaku UKM dalam mengikuti program kemitraan selain persepsi. Keinginan yang kuat para pelaku UKM dalam mengembangkan jenis usahanya, menambah pengalaman dalam menggeluti dunia usaha, serta dorongan untuk mendapatkan kesejahteraan yang lebih, menjadi sebuah motivasi para pelaku UKM dalam mengikuti PKBL.
Dengan mengacu kepada aturan Menteri BUMN PER.05/MBU/2007 tanggal 27 April 2007, pelaksanaan CSR dilingkungan PT.Angkasa Pura II (Persero) dikembalikan dalam dua aspek, yakni program kemitraan dan program bina lingkungan. Dengan kebijakan pengembangan kemitraan, diharapkan situasi sosial-ekonomi masyarakat setempat dapat meningkat, sehingga keberadaan perusahaan dikawasan tersebut akan dirasakan secara langsung manfaatnya oleh warga. Hal tersebut merupakan salah satu faktor motivasi yang membuat UKM di provinsi jambi tertarik untuk mengikuti program kemitraan dari PT. AP II Bandara Sultan Thaha Jambi.

Pada persamaan substruktural dua, dalam melihat pengaruh terhadap kesejahteraan UKM (Y2), keikutsertaan program kemitraan UKM (Y1) menjadi faktor yang berpengaruh terhadap kesejahteraan UKM dengan nilai koefisien jalur sebesar 0,917 . Hal ini menunjukkan bahwa dengan keputusan para pelaku UKM ikut serta dalam PKBL AP II Bandara St. Thaha Jambi yang dicerminkan oleh aktifnya para peserta untuk mengikuti secara baik program pembinaan yang diberikan, secara signifikan telah memengaruhi kesejahteraan mereka.

Meningkatnya kesejahteraan para pelaku UKM mitra binaan PT. AP II Bandara St. Thaha Jambi di Provinsi Jambi ditunjukkan dengan meningkatnya pendapatan mereka sebelum dan sesudah mengikuti program binaan. Berdasarkan hasil uji-t untuk melihat perbedaan antara pendapatan sebelum mengikuti program kemitraan dan setelah mengikuti program, didapatkan bahwa terdapat signifikansi nilai-p $(0,000)$. Hal ini menunjukkan bahwa terdapat perbedaan ratarata pendapatan sebelum program (2,42 juta Rupiah) dengan rata-rata pendapatan setelah mengkuti program (3.337 juta Rupiah). Indikator kesejahteraan masyarakat yaitu tingkat kepuasan dan kesejahteraan adalah dua pengertian yang saling berkaitan. Tingkat kepuasan merujuk kepada keadaan individu atau kelompok, sedangkan tingkat kesejahteraan mengacu kepada keadaan komunitas atau masyarakat luas. Permasalahan kesejahteraan sosial yang berkembang dewasa ini menunjukkan bahwa ada warga negara yang belum terpenuhi hak atas kebutuhan dasarnya secara layak karena belum memperoleh pelayanan sosial dari negara. Akibatnya, masih ada warga negara yang mengalami hambatan pelaksanaan fungsi sosial sehingga tidak dapat menjalani kehidupan secara layak dan bermartabat. 
Pengaruh tidak langsung persepsi terhadap kesejahteraan UKM ditunjukkan dengan nilai koefisien jalur, yakni 0,456. Para pelaku UKM sudah memiliki persepsi bahwa tingkat kesejahteraan mereka akan meningkat setelah mengikuti program binaan PT. AP II Bandara St. Thaha Jambi di Provinsi Jambi. Pengaruh Corporate Relation Program terhadap kesejahteraan hidup, yaitu implementasi pogram kemitraan atau CSR merupakan realisasi dan aktualisasi dari upaya perusahaan untuk terus dekat dengan masyarakat.

Memahami CSR atau program kemitraan sebagai kebertanggung jawaban entitas laba atas dampak operasionalnya maka seharusnya praktik CSR juga melingkupi sektor industri lain. Bahkan di banyak negara, komitmen keseimbangan triple bottom line juga melingkupi industri keuangan, properti, media, komunikasi, teknologi, dan juga dalam ranah perangkat pemerintahannya dan di kalangan masyarakat sipil. 20 Dalam hal ini, jika sebelumnya pijakan tanggung jawab perusahaan hanya terbatas pada sisi finansial saja (single bottom line), kini dikenal konsep triple bottom line, yaitu bahwa tanggung jawab perusahaan berpijak pada 3P (profit, people, planet). Menurut Freeman (1984) dengan semakin berkembangnya konsep CSR ini maka banyak teori yang muncul yang diungkapkan berbagai pihak mengenai CSR ini.

\section{Implikasi manajerial}

Program Kemitraan yang dilakukan oleh PKBL PT. AP II Bandara St. Thaha Jambi dalam memberikan bantuan kepada UKM masyarakat di Provinsi Jambi telah dilaksanakan dengan baik sesuai dengan amanat peraturan Menteri Negara BUMN. Namun, masih harus melakukan pengawasan (controlling) terhadap kondisi di lapangan dari UKM mitra binaan dalam menghadapi dan menyeselaikan hambatan atau kendala yang terjadi. Melakukan pertemuan bagi UKM yang bermasalah dari segi pengembangan usaha baik itu akibat musibah bencana alam ataupun produk yang dihasilkan.

Bagi UKM yang telah berhasil dalam melakukan kegiatan usaha dan pengembangan usaha harus mau bekerja sama dan membantu UKM lainnya yang mengalami kesulitan dalam memasarkan produk atau jaringan. Sehingga kegiatan sharing dan pembentukan perkumpulan pengusaha juga harus dibentuk sebagai wadah aspirasi dan kagiatan untuk saling memberikan masukan dan saran demi kemajuan usaha yang dijalankan dan meningkatkan kesejahteraan peserta program kemitraan UKM mitra binaan PKBL PT.AP II Bandara St. Thaha Jambi.

\section{KESIMPULAN DAN SARAN}

\section{Kesimpulan}

Hasil penelitian menunjukkan bahwa program kemitraan dalam memberikan bantuan kepada UKM masyarakat di Provinsi Jambi telah dilaksanakan dengan baik sesuai dengan amanat peraturan Menteri Negara BUMN, persepsi dan motivasi berpengaruh signifikan terhadap program kemitraan sedangkan hambatan tidak berpengaruh signifikan terhadap program kemitraan, Keikutsertaan program kemitraan berpengaruh signifikan terhadap kesejahteraan UKM di Provinsi Jambi, dan perubahan tingkat kesejahteraan UKM berpengaruh signifikan terhadap Program Kemitraan.

\section{Saran}

Penelitian selanjutnya bisa dilakukan dengan menggunakan analisis terhadap kombinasi antara program kemitraan dan program bina lingkungan serta menambahkan beberapa faktor-faktor lainnya yang mungkin memengaruhi keikutsertaan program kemitraan dan kesejahteraan UKM. Penelitian juga bisa dikembangkan dengan melakukan penelitian di BUMN lainnya, khususnya memiliki Unit PKBL dan kemudian membandingkannya dengan hasil penelitian di BUMN lainnya yang ada di Indonesia atau Negara lainnya.

\section{DAFTAR PUSTAKA}

Dillon WR, Goldstein M. 1984. Multivariate Analysis Methods and Application. New York: John WileydanSons Inc.

Elkington. J. 1997. Cannibals with Forks: the Triple Bottom Line of 21st Century Business. Oxford: Capstone.

Idrus M. 2009. Metode Penelitian Ilmu Sosial. Jakarta: Erlangga.

Johnson RA, Wichern DW. 1992. Applied Multivariate Statistical Analysis. New Jersey: Prentice Hall Englewood Clifs. 
Joreskog KG, Sorbom D. 1993. Lisrel 8: Structural Equation Modeling with the Simplis Command Language. Chicago: SSI Inc.

[KEPMEN] Keputusan menteri BUMN. 2003. No. KEP.236/MBU/2003 Tanggal 17 Juni 2003 tentang Program Kemitraan BUMN dan Bina Lingkungan. Jakarta: KEPMEN BUMN.

[KEPMEN] Keputusan menteri BUMN. 2012. No.KEP.100/MBU/2002 Tanggal 4 Juni 2002. Jakarta: KEPMEN BUMN.

Kotler P. 2000a. Marketing Management: Analysis, Planning, Implementation, and Control. Ed. 9th. New Jersey: Prentice Hall International Int.

[PERMEN] Peraturan Menteri BUMN. 2007. Per-5/ MBU/2007 tentang Program Kemitraan dan Bina Lingkungan. Jakarta: PERMEN BUMN.

Riduwan. 2004. Metode dan Teknik Menyusun Tesis. Bandung: Alfabeta.

Rosid A. 2008. Modul manajemen UMKM. Universitas Mercu Buana Jakarta. Https://pksm.mercubuana. ac.id/new. [16 Oktober 2016].

Suistyo H, Diatama A. 2011. Model optimalisasi kemitraan UKM (Usaha Kecil Menengah) dan BUMN (Badan Usaha Milik Pemerintah) melalui program kemitraan dan bina lingkungan (PKBL) untuk meningkatkan kinerja UKM. Riptek Magister Universitas Islam Sultan Agung 5(II): 25-40.

Sutisna. 2001. Perilaku Konsumen dan Komunikasi Pemasaran. Bandung:PT. Remaja Rodakarya.

Tika MP. 2006. Metodologi Riset Bisnis. Jakarta: PT Bumi Aksara.
Umar H. 1998. Riset Sumber Daya Manusia. Jakarta: Gramedia Pustaka Utama

[UU] Undang-Undang. 1995. Undang-undang Repulik Indonesia No. 9 Tahun 1995 pasal 21. Ayat D tentang Usaha Kecil. Jakarta: UU.

[UU] Undang-Undang. 2003. Undang-Undang Nomor 19 Tahun 2003 tentang Badan Usaha Milik Negara. Jakarta: UU.

[UU] Undang-Undang. 2007. Undang Undang-Undang Nomor 25 Tahun 2007 tentang Penanaman Modal. Jakarta: UU.

[UU] Undang-Undang. 2007. Undang-Undang Nomor 40 Tahun 2007 tentang Perseroan Terbatas. Jakarta: UU.

[UU] Undang-Undang. 2008. Undang-Undang Nomor 20 Tahun 2008 tentang Usaha Mikro, Kecil dan Menengah. Jakarta: UU.

[UU] Undang-Undang. 2008. Nomor 20 tahun 2008 tentang Usaha Mikro, Kecil dan Menengah (UMKM). Jakarta: UU.

[UU] Undang-Undang. 2009. Undang-Undang Nomor 11 Tahun 2009 tentang Kesejahteraan Sosial bahwa kesejahteraan sosial pasal 1 ayat 1. Jakarta: UU.

Wardoyo. 2005. Kinerja lembaga keuangan mikro bagi upaya penguatan usaha mikro kecil dan menengah di wilayah Jabotabek. http://psp3.ipb. ac.id/. [3 Oktober 2016].

Widjaja G, Pratama YA. 2008. Risiko Hukum dan Bisnis Perusahaan Tanpa CSR. Jakarta: PT. Percetakan Penebar Swadaya. 